\title{
Malignant Fibrous Histiocytoma of the Spermatic Cord: Report of Two Cases and Review of the Literature
}

\author{
Bryan Tzy-Young Lin, M.D., Ph.D., Dean A. Harvey, M.D., L. Jeffrey Medeiros, M.D. \\ Department of Surgical Pathology (BT-YL), Tarzana Regional Medical Center, Tarzana, California; \\ Department of Pathology (DAH), Santa Monica-UCLA Medical Center, Santa Monica, California; and \\ Division of Pathology and Laboratory Medicine (LJM), University of Texas MD Anderson Cancer Center, \\ Houston, Texas
}

Malignant fibrous histiocytoma (MFH) of the spermatic cord is rare, and most published cases are single case reports that emphasize clinical presentation and management. We describe in detail the histopathologic features of 2 cases of high-grade storiform-pleomorphic MFH arising in the spermatic cord. Both tumors occurred in elderly men, 65 years and 70 years, and were $4 \mathrm{~cm}$ (Case 1) and 5 $\mathrm{cm}$ (Case 2) in greatest dimension. The tumor mass in Case 1 was associated with satellite tumor nodules. At last follow-up, in Case 1 the patient died of metastasis, and in Case 2, the patient is alive and well 46 months after diagnosis. Review of the literature reveals 33 additional cases published in English (17 cases) or Japanese (16 cases) that include histologic description. Including the 2 cases in this report, most of the tumors occurred in older (than 50 years) patients ( 28 of 35 cases, $80 \%$ ) and occurred as solitary masses that ranged in diameter from less than $1 \mathrm{~cm}$ to more than $20 \mathrm{~cm}$. Nine patients presented with satellite tumor nodules. Twenty-nine (83\%) tumors were of the storiformpleomorphic type, with 3 giant cell type, 2 inflammatory type, and 1 myxoid type. These features do not differ significantly from MFH in other anatomic sites. Clinical follow-up is available in 33 cases (3174 months; mean, 31.5 months). Twelve patients developed recurrence and metastasis; at least 4 patients died of the disease. Tumor size does not predict the clinical progression; however, patients with progressive tumors were commonly associated with satellite nodules at time of presentation, an indication of early local metastasis.

Copyright (C) 2002 by The United States and Canadian Academy of Pathology, Inc.

VOL. 15, NO. 1, P. 59, 2002 Printed in the U.S.A.

Date of acceptance: September 5, 2001.

Address reprint requests to: Bryan Tzy-Young Lin, M.D., Ph.D., Department of Surgical Pathology, Tarzana Regional Medical Center, 18321 Clark Street, Tarzana, CA 91356; fax: 818-708-5546.
KEY WORDS: Malignant fibrous histiocytoma, Malignant lymphoma, Paratesticular tissue, Sarcoma, Spermatic cord.

Mod Pathol 2002;15(1):59-65

Malignant mesenchymal tumors of the spermatic cord in adults are rare (1-3). Although malignant fibrous histiocytoma (MFH) is the most common sarcoma in adults, usually occurring in the retroperitoneum and lower extremities, MFH rarely involves the spermatic cord (4). We recently encountered two cases of MFH involving the spermatic cord and paratesticular area. Our review of the literature revealed 33 additional cases described in English or Japanese, mostly emphasizing the clinical presentation and treatment of these tumors. Histopathologic data are incomplete in many of these cases. In this report, we describe the clinical, histopathologic and immunohistochemical features of two new cases.

\section{MATERIALS AND METHODS}

The cases were selected from the surgical pathology files of the Tarzana Regional Medical Center (Case 1) and the Santa Monica-UCLA Medical Center (Case 2) Hematoxylin and eosin-stained slides were reviewed by all authors, and paraffin blocks were selected for immunohistochemical studies. Clinical follow-up was obtained by direct communication with the primary care physicians and urologists.

Immunohistochemical evaluation was performed using formalin-fixed paraffin-embedded tissue sections, commercially available antibodies, and heatinduced epitope retrieval as described previously (5). The source and dilution of the primary antibodies (monoclonal unless otherwise specified) were as follows: vimentin (V9, 1:100), S100 (polyclonal, 1:200), desmin (D33, 1:150), CD68 (KP-1, 1:500), CD117 (polyclonal, 1:200), lysozyme (polyclonal, 1:1000), and epithelial membrane antigen (E29, 
1:50; DAKO, Carpinteria, CA); cytokeratin (a cocktail of antibodies AE1, AE3, CAM 5.2, and $35 \beta \mathrm{H} 11$, prediluted; Ventana, Tucson, AZ); CD34 (My10, 1:30, Becton-Dickinson, San Jose, CA); smooth muscle actin (1A4, 1:8000, Sigma, St. Louis, MO), and muscle-specific actin (HHF35, 1:8000, Enzo Biochemicals, New York, NY).

\section{Case Histories, Surgical Findings, and Follow-Up}

\section{Case 1}

A 65-year-old man had a painless slow-growing mass of the right scrotum. Urologic examination revealed an enlarged right scrotum with a large multinodular mass focally adherent to the scrotum. No inguinal nodes were palpable. Ultrasonogram revealed a paratesticular mass adjacent to, but not involving the testicle. Right radical orchiectomy was performed, and the specimen revealed several multinodular firm tumor masses adjacent to and superior to the testicle. The testicle was $3 \mathrm{~cm}$ and not involved grossly by tumor. The largest tumor, located in the midportion of spermatic cord, was 4 $\mathrm{cm}$ in diameter and multinodular. The cut surface of the tumor was elastic and tan-pink with central yellow discoloration. Several smaller tumors were identified in the paratesticular tissue, including a 2 -cm nodule adherent to the epididymis. The cut surfaces of these smaller tumors were gray-tan, homogenous, and firm. Surgical resection margins were free of tumor.

The patient had an uneventful recovery after surgery. At two months' follow-up, he was found to have elevated serum prostate specific antigen (PSA). Ultrasonogram revealed an enlarged prostate with rightsided nodularity. Core needle biopsies of the prostate revealed adenocarcinoma in the right lobe, in $10 \%$ of the specimen, with a Gleason score of $3+4=7$, and a small focus of adenocarcinoma in the left lobe (less than $1 \%$ of the specimen). At this time, a growing mass was noticed in the right groin area near the previous excision site. Surgical exploration (3 months after the initial surgery) revealed a $6-\mathrm{cm}$ ill-defined tumor morphologically consistent with recurrent MFH. Six months after the initial surgery, a lytic lesion involving the $\mathrm{T} 6$ vertebral body was identified. A computer-assisted tomography-guided fine needle aspiration biopsy showed high-grade malignant cells morphologically similar to the original MFH, consistent with metastasis. The patient received radiation therapy to the inguinal region and spine but developed liver and lung metastases and died shortly thereafter. Autopsy was not performed.

\section{Case 2}

A 75-year-old man presented with a right scrotal mass. An intraoperative biopsy revealed possible sarcoma, and a right radical orchiectomy was per- formed. The specimen was a $4.5-\mathrm{cm}$ right testicle with $11 \mathrm{~cm}$ of attached spermatic cord and a $5 \times 3$ $\times 1.5-\mathrm{cm}$ paratesticular mass. The mass was external to the tunica vaginalis and surrounded the vas deferens with extension to adjacent muscle, without involvement of epididymis or testicle. The cut surface of the tumor was gray-pink to tan and firm with ill-defined nodules. Surgical resection margins were free of tumor. The patient had an uneventful recovery after surgery and was clinically free of tumor at 46 months of follow-up.

\section{Histopathologic Findings}

In Case 1, the largest tumor was composed of spindle-shaped tumor cells arranged in fascicles with a storiform pattern intermixed with many short blood vessels and few inflammatory cells (Fig. 1A). Individual tumor cells had a large nucleus, vesicular chromatin, one small distinct nucleolus, and a moderate amount of gray cytoplasm with indistinct cell borders (Fig. 1B). Peripheral to the storiform areas was a less cellular rim of fibrotic tissue with a vague storiform pattern containing scattered large pleomorphic tumor cells (Fig. 1C). At the edge of the tumor, areas of myxoid change and coagulative necrosis were present. Sections of the smaller tumor nodules revealed spindle cells arranged in loose fascicles intermixed with numerous inflammatory cells, including neutrophils, eosinophils, plasma cells, and small lymphocytes (Fig. 1D). A few microabscesses and scattered rare pleomorphic tumor giant cells were identified. These findings were characteristic of highgrade pleomorphic-storiform MFH with focal myxoid and inflammatory patterns. The tumor did not involve the testicle or epididymis, and no invasion of lymphatic or vascular spaces was identified.

In Case 2, the tumor had two distinct patterns: hypercellular areas with numerous spindle-shaped tumor cells arranged in a storiform pattern with short fascicles (Fig. 2A) and less cellular areas containing pleomorphic tumor giant cells and an inflammatory infiltrate (Fig. 2B). In the less cellular areas, the pleomorphic tumor cells had markedly enlarged nuclei with irregular nuclear contours, granular chromatin, and abundant gray cytoplasm (Fig. 2C). Many tumor giant cells were present, and some cells resembled Reed-Sternberg cells. The inflammatory infiltrate was predominantly small lymphocytes and plasma cells (Fig. 2D). These features were characteristic of MFH with a high-grade pleomorphic-storiform pattern. The tumor was confined to the paratesticular area with no involvement of testicle, epididymis, or tunica vaginalis.

\section{Immunohistochemical Findings}

In both cases, the tumor cells were positive for vimentin, CD68, and lysozyme and were negative 

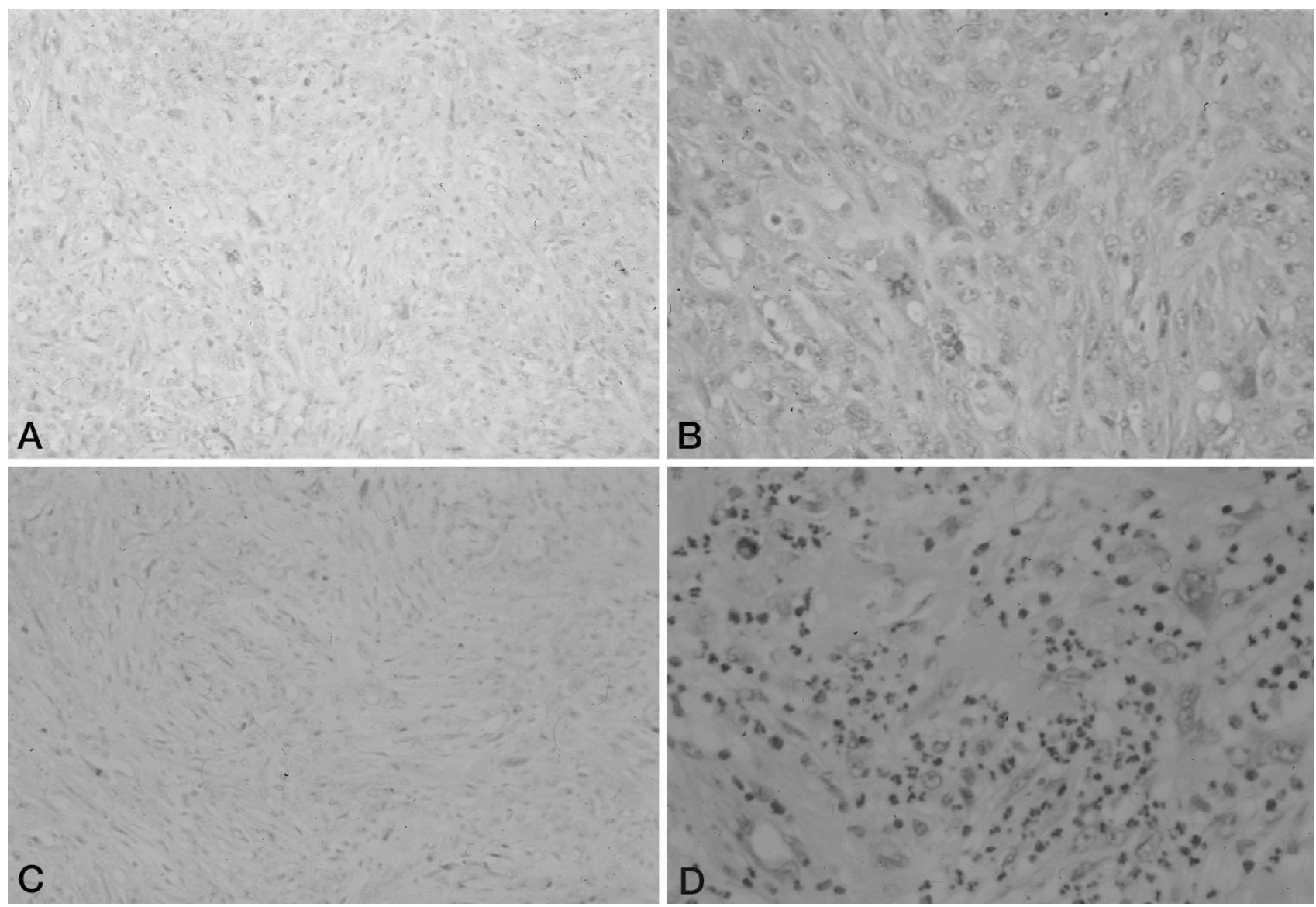

FIGURE 1. Case 1. A, sections of the main tumor mass. Spindle-shaped tumor cells with a storiform pattern and scattered giant cells. B, highpower view of the main tumor. Individual tumor cells have a pleomorphic appearance, high-grade nuclear features, and indistinct cell borders. $\mathbf{C}$, less cellular area of the main tumor. Scattered pleomorphic tumor cells with abundant extracellular collagen bundles and a vague storiform pattern. D, sections of the satellite tumor nodules. Rare pleomorphic tumor giant cells in a background of inflammatory cells.

for cytokeratin, S100, desmin, smooth muscle actin, muscle-specific actin, CD34, epithelial membrane antigen, and CD117. These results are consistent with fibroblastic or histiocytic lineage. There was no support for origin from smooth or skeletal muscle, adipose tissue, melanocytes, or epithelium.

\section{DISCUSSION}

Malignant fibrous histiocytoma is one of the most common adult sarcomas and the most commonly involved sites include the lower extremities and retroperitoneum (4). Malignant fibrous histiocytoma of the spermatic cord and paratesticular area in adults are rare. There are 17 cases described in English, and 16 cases in Japanese (6-36). The clinical features of most of these cases have been reviewed by Glazier et al. (34) and Mitsumori et al. (32). Thirty-five cases, including the two new cases in this report, have a description of the histopathologic findings and are listed in Table 1 . The age at time of diagnosis ranged from 32-84 years, with most patients over 50 years (less than 40 years: 1 ; $40-49$ years: $6 ; 50-59$ years: $6 ; 60-70$ years: 8 ; more than 70 years: 14). The size of the tumors varied from small (less than $1 \mathrm{~cm})$, to very large $(27 \mathrm{~cm})$, and most were in the $2-10-\mathrm{cm}$ range $(0-2 \mathrm{~cm}: 4$ tumors; 2-5 cm: 13 tumors; 5-10 cm: 11 tumors; more than $10 \mathrm{~cm}$ : 6 tumors; unknown: 1 tumor). Most tumors have been a localized solitary mass, although some cases had multiple satellite tumor nodules (9 cases), and rare cases had involvement of scrotal skin ( 2 cases).

Histopathologically, most tumors (29 cases) were of the storiform-pleomorphic type. Various numbers of tumor giant cells were noted in 25 cases, and 3 cases were classified as giant cell type. Nine cases had focal areas of myxoid change and 1 case was classified as myxoid type. The presence of moderate acute or chronic inflammation was noted in 7 cases (20\%), and 2 cases were classified as inflammatory type. One case had focal osteoid formation (Case 12). One case had positive surgical resection margins. Ultrastructural studies were performed in 6 cases, with features characteristic of a fibrohistiocytic proliferation (Cases 1, 5, 6, 16, 19, and 22).

The treatment and outcome of these patients varied. Most patients received radical orchiectomy 

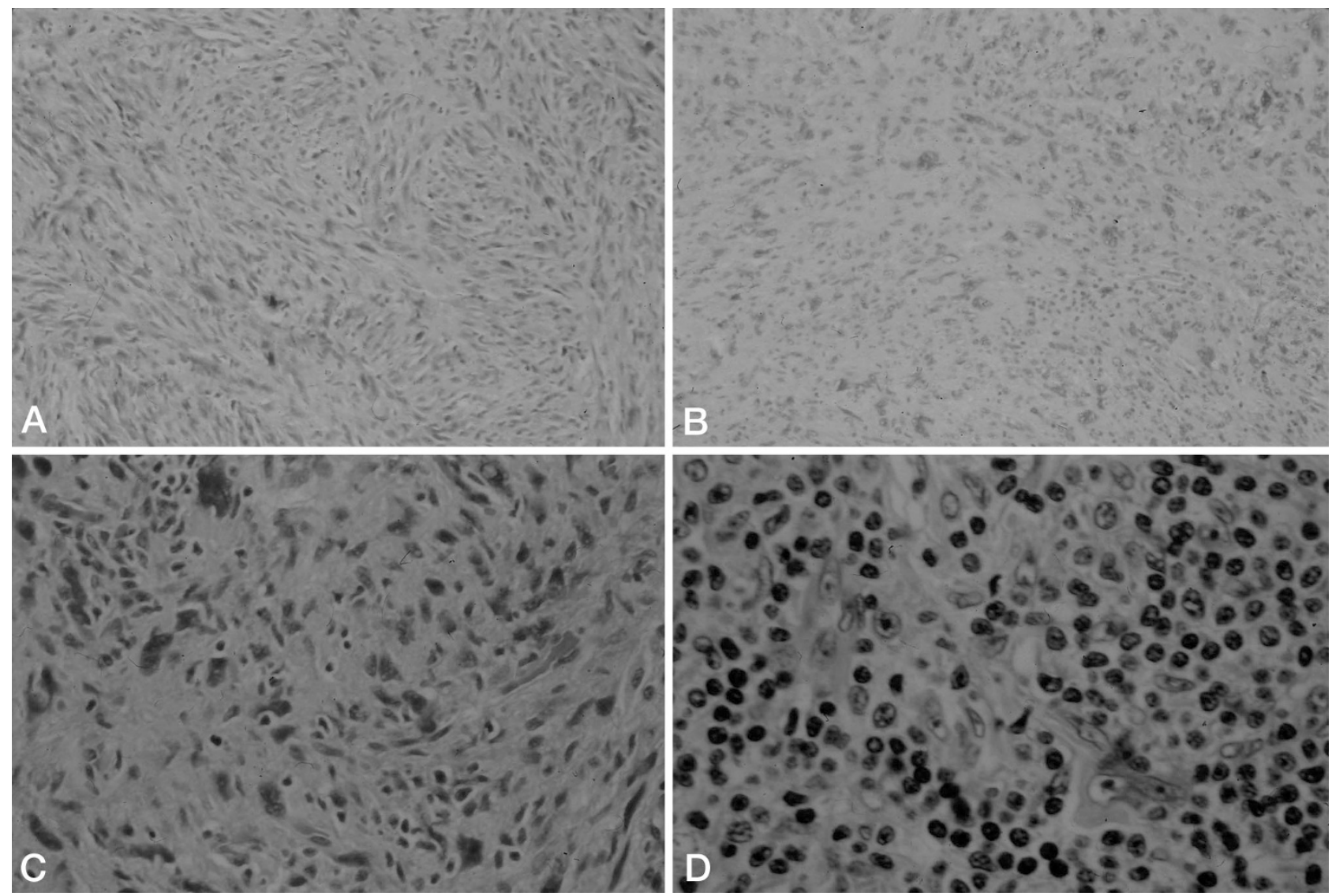

FIGURE 2. Case 2. A, spindle cell tumor with a storiform pattern and scattered pleomorphic tumor giant cells. B, less cellular areas with many pleomorphic tumor cells in a background of inflammatory infiltrate. C, high-power view of the less cellular area. Large pleomorphic tumor cells and giant cells with lymphoid infiltrate. $\mathbf{D}$, a lymphoid aggregate with large pleomorphic tumor cells.

with local wide excision (33 cases). Nine patients had surgery and local radiation or systemic chemotherapy; six had radiation and chemotherapy. One patient received only radiotherapy after biopsy (Case 25). Clinical follow-up was provided in 33 cases. Most patients were alive without recurrence with 3 months to 13 years of follow up (21 cases). Recurrence or metastasis was noted in 12 patients, and at least 4 patients died of metastatic tumor. In the patients with progressive tumors, 4 had satellite tumor nodules at time of presentation, including our Case 1. The size of the progressive tumors varied from less than $1 \mathrm{~cm}$ to $15 \mathrm{~cm}$, not significantly different from that in the nonprogressive cases. Two patients developed prostatic adenocarcinoma during the follow-up interval; one had received radiation therapy (Case 10), and one patient did not receive treatment before dying of MFH (our Case 1).

Tumors arising from the spermatic cord and paratesticular areas are rare and are usually grouped according to their histologic differentiation into mesenchymal, epithelial, germ cell, mesothelial, and lymphoid tumors. These entities are to be excluded in establishing the diagnosis of MFH.
Lipoma and liposarcoma are the most common mesenchymal tumors of the paratesticular area and spermatic cord in adults $(1,2,37)$. Typically, multiloculated lipoblasts and areas of lipomatous differentiation can be identified in liposarcoma. In the cases we report, a few pleomorphic tumor cells had vacuolated cytoplasm resembling lipoblasts, but no distinct lipomatous areas were identified in multiple histologic sections. Dedifferentiated liposarcomas can have areas showing high grade sarcoma similar or identical to MFH (38). In these tumors, liposarcomatous areas are also found, allowing the diagnosis to be established. In difficult cases in which lipoblasts are very rare, the cells can be identified by positive immunostaining for S100 or leptin (39). The morphologic features of the two cases we report and the negativity for S100 exclude the diagnosis of liposarcoma.

Paratesticular rhabdomyosarcoma, leiomyosarcoma, and solitary fibrous tumor have been described in adults. These tumors have characteristic morphologic features and immunostaining profiles $(40,41)$. The overall morphologic features and the absence of specific antigen expression in the cases we report exclude these diagnoses. 


\begin{tabular}{|c|c|c|c|c|c|c|c|c|c|}
\hline \multirow{2}{*}{$\begin{array}{l}\text { Case No. } \\
\text { (Reference) }\end{array}$} & \multirow{2}{*}{$\begin{array}{l}\text { Age } \\
\text { (y) }\end{array}$} & \multirow[b]{2}{*}{ Side/Size $(\mathrm{cm})$} & \multirow[b]{2}{*}{ Gross } & \multicolumn{4}{|c|}{ Histopathology Pattern } & \multirow[b]{2}{*}{ Therapy } & \multirow[b]{2}{*}{ Clinical Follow-Up } \\
\hline & & & & $\begin{array}{l}\text { Storiform- } \\
\text { pleomorphic }\end{array}$ & Myxoid & Giant Cell & Inflammatory & & \\
\hline $1(6)$ & 72 & $\mathrm{R} / 3 \times 3 \times 3$ & & + & & + & & S & $\begin{array}{l}\text { local recur, } 4 \mathrm{mo} \text {, } \\
\text { lung met at } 1 \mathrm{y}\end{array}$ \\
\hline $2(7)$ & 79 & $\mathrm{R} / 8$ & Multiple & + & & + & & S & $\begin{array}{l}\text { DOD, } 4.5 \text { y with } \\
\text { lung met }\end{array}$ \\
\hline $3(8)$ & 53 & $\begin{array}{l}\mathrm{L} / 6.5 \times 6.2 \times \\
\quad 2.8\end{array}$ & & + & & + & & S & $\mathrm{A} \& \mathrm{~W}, 13 \mathrm{y}$ \\
\hline $4(9)$ & 81 & $\mathrm{R} / 11 \times 8 \times 7$ & & + & & & & $\mathrm{S}$ & DSD, 3 y \\
\hline $5(10)$ & 76 & $\mathrm{R} / 10$ & & + & & + & & $\mathrm{s}$ & $\mathrm{A} \& \mathrm{~W}, 22 \mathrm{mo}$ \\
\hline $6(10)$ & 52 & $\mathrm{~L} / 10 \times 15$ & & + & & + & + & S, RT, C & $\begin{array}{l}\text { local recur } 22 \mathrm{mo} \\
2+\text { nodes }\end{array}$ \\
\hline $7(10)$ & 66 & $\mathrm{~L} / 1 \times 4$ & & + & & + & & $\mathrm{s}$ & $\mathrm{A} \& \mathrm{~W}, 16 \mathrm{mo}$ \\
\hline $8(11)$ & 55 & $\mathrm{R} / 2 \times 2$ & $\begin{array}{c}\text { Multiple, } \\
\text { node }+\end{array}$ & + & & G & & S, RT & $\mathrm{A} \& \mathrm{~W}, 8 \mathrm{mo}$ \\
\hline $9(12)$ & 46 & $\begin{array}{l}\mathrm{R} / \text { small } \\
\text { nodules }\end{array}$ & Multiple & + & & & & $\mathrm{S}, \mathrm{RT}$ & $\begin{array}{l}\text { DOD } 27 \text { mo with } \\
\text { lung met }\end{array}$ \\
\hline $10(13)$ & 72 & $\mathrm{~L} / 4 \times 3.5 \times 4$ & & + & & + & & S, RT & $\mathrm{A} \& \mathrm{~W}, 1.5 \mathrm{y}$ \\
\hline $11(14)$ & 32 & $\mathrm{~L} / 6 \times 6$ & & + & & + & & $\mathrm{s}$ & $\mathrm{A} \& \mathrm{~W}, 14.5 \mathrm{y}$ \\
\hline $12(15)$ & 54 & $\mathrm{~L} / 3,2.5$ & Two & + & + & & & & $\mathrm{N} / \mathrm{A}$ \\
\hline $13(16)$ & 70 & $\begin{array}{l}\mathrm{R} / 7.2 \times 3.4 \times \\
3.5\end{array}$ & & + & & + & & S, RT, C & $\mathrm{A} \& \mathrm{~W}, 7 \mathrm{mo}$ \\
\hline $14(17)$ & 69 & $\mathrm{R} / 3 \times 2 \times 2$ & & + & & + & & S & $\mathrm{A} \& \mathrm{~W}, 12 \mathrm{mo}$ \\
\hline $15(18)$ & 75 & $\mathrm{~L} / 6 \times 6 \times 8$ & & + & & + & & S, RT & $\mathrm{A} \& \mathrm{~W}, 6 \mathrm{mo}$ \\
\hline $16(19)$ & 84 & $\mathrm{~L} / 8 \times 9,1.5$ & Multiple & + & & + & + & $\mathrm{s}$ & local recur at $3 \mathrm{y}$ \\
\hline $17(20)$ & 75 & $\mathrm{R} /$ hen egg & & + & + & & & S, RT & $\mathrm{A} \& \mathrm{~W}, 19 \mathrm{mo}$ \\
\hline $18(21)$ & 70 & L/biopsy & & + & & + & & S, RT & local recur at $2 \mathrm{y}$ \\
\hline $19(22)$ & 48 & $\mathrm{~L} / 2 \times 2 \times 1.5$ & $\begin{array}{l}\text { Margin } \\
+\end{array}$ & + & & + & & S, RT, C & $\begin{array}{l}\text { local recur at } 1.5 \\
\text { mo and } 6 \text { mo }\end{array}$ \\
\hline $20(23)$ & 76 & $\mathrm{R} / 12 \times 8 \times 5$ & & + & & + & & S & $\mathrm{A} \& \mathrm{~W}, 16 \mathrm{mo}$ \\
\hline $21(24)$ & 67 & $\mathrm{R} / 5 \times 4.5 \times 4$ & & + & & + & I & S, RT, C & A\&W, 7 mo \\
\hline $22(25)$ & 74 & $\begin{array}{l}\mathrm{R} / 10.5 \times 4 \times \\
\quad 3.5\end{array}$ & $\begin{array}{c}\text { multiple } \\
\text { vein+ }\end{array}$ & + & + & + & I & S & $\mathrm{A} \& \mathrm{~W}, 11 \mathrm{mo}$ \\
\hline $23(26)$ & 81 & $\mathrm{~L} / 2 \times 2 \times 3$ & & + & + & + & & $\mathrm{S}$ & lung met at $9 \mathrm{mo}$ \\
\hline $24(27)$ & 62 & $\mathrm{~L} / 12 \times 13 \times 9$ & & + & & & & S, RT, C & $\begin{array}{l}\text { DOD, lung met at } \\
1 \mathrm{y}\end{array}$ \\
\hline $25(28)$ & 59 & $\begin{array}{l}\mathrm{R} / 4.5 \times 3.5 \times \\
2.5\end{array}$ & multiple & + & + & + & & S & $\mathrm{A} \& \mathrm{~W}, 2 \mathrm{y}$ \\
\hline $26(29)$ & 44 & $\mathrm{R} / 5$ & & + & M & + & & $\mathrm{S}$ & local recur, $17 \mathrm{mo}$ \\
\hline $27(30)$ & 49 & $\mathrm{R} / 9 \times 7 \times 9$ & & + & & & + & S, RT, C & local recur, 3 y \\
\hline $28(31)$ & 40 & $\begin{array}{l}\mathrm{L} / 3.5 \times 2.7 \times \\
\quad 3\end{array}$ & & + & & G & & $\mathrm{S}$ & $\mathrm{A} \& \mathrm{~W}, 12 \mathrm{y}$ \\
\hline $29(32)$ & 44 & $\mathrm{~L} / 1.5 \times 1$ & & + & & & & $\mathrm{s}$ & $\mathrm{A} \& \mathrm{~W}, 8 \mathrm{mo}$ \\
\hline $30(33)$ & 75 & $\mathrm{R} / 6.5$ & & + & + & & & $\mathrm{S}$ & $\mathrm{A} \& \mathrm{~W}, 2 \mathrm{y}$ \\
\hline $31(34)$ & 64 & $\mathrm{~L} / 7 \times 3 ; 6 \times 4$ & multiple & + & + & & & $\mathrm{S}, \mathrm{RT}$ & $\mathrm{A} \& \mathrm{~W}, 20 \mathrm{mo}$ \\
\hline $32(35)$ & 78 & $\begin{array}{l}\mathrm{L} / 27 \times 22 \times \\
\quad 17\end{array}$ & & + & & + & & & N/A \\
\hline $33(36)$ & 52 & $\mathrm{~L} / 6 \times 4 \times 3$ & & + & & G & & S, RT & $\mathrm{A} \& \mathrm{~W}, 3 \mathrm{mo}$ \\
\hline 34 & 65 & $\mathrm{R} / 4$ & multiple & + & + & & + & $\mathrm{S}, \mathrm{RT}$ & $\begin{array}{l}\text { DOD, lung met at } \\
7 \text { mo }\end{array}$ \\
\hline 35 & 75 & $\mathrm{R} / 5 \times 3 \times 1.5$ & & + & & + & + & $\mathrm{s}$ & $\mathrm{A} \& \mathrm{~W}, 46 \mathrm{mo}$ \\
\hline
\end{tabular}

L, left; R, right; +, present focally; M, myxoid type; G, giant cell type; I, inflammatory type; S, surgery; RT, radiation therapy; C, chemotherapy; A\&W, alive and well without disease; DOD, died of disease; DSD, died without disease; N/A, not available; recur, recurrence; met, metastasis.

Fibrosarcoma in the paratesticular region and spermatic cord is rare, and, in the past, many cases of MFH involving any anatomic site were categorized as fibrosarcoma. In tumors with a characteristic storiform-pleomorphic pattern, in particular if associated with morphologic or immunophenotypic evidence of histiocytic differentiation, we believe it is best to categorize these tumors as MFH, as in both our cases.

Malignant mesotheliomas involving the paratesticular area are rare. The epithelial and biphasic types of mesothelioma can be excluded by the lack of epithelial cell features and the absence of keratin immunostaining. Sarcomatous mesotheliomas can have an immunophenotype similar to MFH and may be a diagnostic challenge. In difficult cases, ultrastructural studies and additional immunostains may be helpful.

In the experience of Folpe and Weiss (1), prominent hyalinization and chronic inflammation are often seen in paratesticular MFH. The presence of an acute or chronic inflammatory infiltrate was noted in the two tumors we report and in five other tumors in the literature $(20 \%)$. These changes may obscure the pleomorphic tumor cells. Thus, a careful search for the tumor cells is needed to avoid the 
misdiagnosis of an inflammatory process or benign fibroma. In addition, the presence of a chronic inflammatory infiltrate and scattered pleomorphic tumor giant cells, some resembling Reed-Sternberg cells, may suggest the possibilities of nonHodgkin's lymphoma and mixed cellularity Hodgkin's disease (HD). Indeed, some cases of inflammatory MFH involving other sites have been erroneously diagnosed as HD or anaplastic large cell lymphoma (4). Careful histologic examination can usually establish the sarcomatous nature and the reactive inflammatory background in these tumors. In difficult cases, utilization of an immunostain panel can be helpful (42). MFH is invariably negative for hematolymphoid markers.

Primary germ cell tumors of the paratesticular region and spermatic cord are most commonly dermoid cysts. Malignant germ cell tumors in these areas are usually an extension of a primary testicular lesion. These tumors usually express epithelial markers, at least focally, and have morphologic features characteristic of primitive germ cells.

The pathogenesis of MFH is unknown. The tumor cells have features suggestive of fibroblastic, myofibroblastic, and/or histiocytic origin and may have developed from the fibrous tissue of the spermatic cord and paratesticular areas, such as tunica albuginea (33). One of the previously reported cases arose in a man who received intratesticular injection of an unknown substance in a Nazi concentration camp 40 years before developing paratesticular MFH (35).

In summary, MFH of the spermatic cord usually occurs in middle-aged to elderly men (50 years or older) and is commonly first detected as a painless growing tumor in the scrotum. Some tumors are multinodular with satellite tumor nodules, which are more commonly associated with recurrence and progression. Most patients with MFH reported in the literature have been treated by radical orchiectomy with wide local excision (43). The size of the tumor does not seem to affect the outcome. Recurrence and metastasis is common (36\%), and the outcome for these patients is poor despite aggressive adjuvant therapy.

Acknowledgments: The authors thank Dr. Hector Battifora for reviewing Case 2 and Dr. Kazuhiko Hayashi of the Okayama University in Japan for retrieving and translating the references in Japanese.

\section{REFERENCES}

1. Folpe AL, Weiss SW. Paratesticular soft tissue neoplasms. Semin Diag Pathol 2000;17:307-18.

2. Srigley JR, Hartwick RW. Tumors and cysts of the paratesticular region. Pathol Annu 1990;25(Pt 2):51-108.
3. Ulbright TM, Amin MB, Young RH. Tumors of the testis, adnexa, spermatic cord, and scrotum. In: Rosai J, editor. Atlas of tumor pathology, 3rd series, Fascicle 25. Washington DC: Armed Forces Institute of Pathology; 1999. p. 265-71.

4. Enzinger FM, Weiss SW. Soft tissue tumors. 3rd edition. St. Louis, MO: Mosby-Year Book; 1995. p. 355-77.

5. Lin BTY, Colby T, Gown AM, Hammar SP, Mertens RB, Churg A, Battifora H. Malignant vascular tumors of the serous membrane mimicking mesothelioma. A report of 14 cases. Am J Surg Pathol 1996;20:1431-9.

6. Ehrlich RM, Tannenbaum M, Fish GW. The application of new scientific techniques in studying urological neoplasia. J Urol 1967;98:120-4.

7. Cole AT, Straus FH, Gill WB. Malignant fibrous histiocytoma: an unusual inguinal tumor. J Urol 1972;107:1005-7.

8. Farah RN, Bohne AW. Malignant fibrous histiocytoma of spermatic cord. Urology 1974;3:782-3.

9. Dias R, Fernandes M, Gaetz HP. Malignant fibrous histiocytoma of spermatic cord. Urology 1978;12:365-7.

10. Williamson JC, Johnson JD, Lamm DL, Tio F. Malignant fibrous histiocytoma of the spermatic cord. J Urol 1980;123: 785-8.

11. Sasaki K, Hirano T, Inoue K. Malignant fibrous histiocytoma of the spermatic cord: a case report. Jpn J Clin Urol 1981;35: 391-4.

12. Adolphs HD, Helpap B, Koischwitz D. Retroperitoneal and inguinal manifestation of malignant fibrous histiocytoma. Urology 1982;20:639-45.

13. Watanabe Y, Matsuyama K, Aoyagi N, Shishido S, Chino T, Chino I, Kudoh K, Chino I, Fukuzumi N. Intrascrotal malignant fibrous histiocytoma. Jpn J Clin Urol 1982;36:677-9.

14. Smailowitz Z, Kaneti J, Sober I, Krugliak L, Sacks M. Malignant fibrous histiocytoma of the spermatic cord. J Urol 1983; 130:150-1.

15. Uemura Y, Izumi H, Morii S, Mikami O, Togawa H. A case of a 54 year old male with malignant fibrous histiocytoma originating in the left scrotum [abstract in Japanese]. Trans Soc Pathol Jpn 1983;72:342-3.

16. Nishimoto T, Morita T, Honda T, Suetake Y. Simoyama N. Pleomorphic fibrous histiocytoma of the spermatic cord: a case report. Jpn J Clin Urol 1983;37:469-71.

17. Murayama K, Katsumi T, Takamatsu O, Watanabe K. Malignant fibrous histiocytoma of the spermatic cord: a case report. Acta Urol Jpn (Hinyokika Kiyo) 1984;30:1269-73.

18. Kohama T, Takada H, Tsuburaya T, Kakuto Y, Ichikawa S, Nishizawa O. A case of malignant fibrous histiocytoma of the spermatic cord. Jpn J Clin Urol 1984;41:437-44.

19. Tanaka T, Akazawa N, Ozaki Y, Matsumura Y, Ohmon H. Malignant fibrous histiocytoma originating in the left spermatic cord with a review of 14 cases in the literature. Jpn J Clin Oncol 1984;14:437-43.

20. Miyagi T, Ohtaki M, Rin S, Matsubara F. Intrascrotal malignant fibrous histiocytoma: a case report and review of the literature. Acta Urol Jpn 1985;31:527-32.

21. Sato K, Noguchi S, Iwasaki A, Ishizuka E. Malignant fibrous histiocytoma of the spermatic cord associated with bladder cancer. Jpn J Urol 1988;50:1041-3.

22. Ito H, Watanabe T, Okita K. Spermatic cord malignant fibrous histiocytoma, a case report [abstract in Japanese]. Jpn J Urol 1987;78:386-7.

23. Tsukada T, Miura K. Malignant fibrous histiocytoma of the spermatic cord: a case report. Jpn J Urol 1989;51:959-61.

24. Algaba F, Trias I, Castro C. Inflammatory malignant fibrous histiocytoma of the spermatic cord with eosinophilia. Histopathology 1989;14:319-21.

25. Nistal M, Regadera J, Jareno E, Paniagua R. Inflammatory malignant fibrous histiocytoma of the spermatic cord. Urol Int 1988;43:188-92. 
26. Komatsu H, Watanabe K. Malignant fibrous histiocytoma of the spermatic cord. Jpn J Clin Urol 1988;42:179-81.

27. Hongoh R, Kigure T, Satoh K, Matsuo S, Sasaki S. A case of malignant fibrous histiocytoma of the spermatic cord. Jpn J Clin Urol 1988;42:929-31.

28. de Bruin MJ, Pelger RC, Meijer WS, Giard RW. Malignant fibrous histiocytoma of the spermatic cord. J Urol 1989;142: 131-3.

29. Fujito S, Kanemura M, Shoji F, Yokoyama M, Nanjou F. Malignant fibrous histiocytoma of the spermatic cord: report of a case. Urol Surg (Jpn) 1991;4:97-100.

30. Kageyama S, Satoh S, Ihara H, Ueda D, Nakano M, Ushiyama T, Ohta N, Tajima A, Kawabe K, Ashiki A. A case of locally recurrent malignant fibrous histiocytoma of the spermatic cord treated with CYVADIC chemotherapy. Urol Surg (Jpn) 1991;4:835-7.

31. Ciancio G, Civantos F, Block NL. Malignant fibrous histiocytoma of spermatic cord. Urology 1993;41:55-9.

32. Mitsumori K, Horri Y, Akao T, Nakagawa T, Ohbayashi T, Sawada S. Malignant fibrous histiocytoma of the spermatic cord: a case report. Acta Urol Jpn 1993;39:1063-6.

33. Eltorky MA, O'Brien TF, Walzer Y. Primary paratesticular malignant fibrous histiocytoma. Case report and review of the literature. J Urol Pathol 1994;1:425-9.

34. Glazier DB, Vates TS, Cummings KB, Pickens RL. Malignant fibrous histiocytoma of the spermatic cord. J Urol 1996;155: 955-7.

35. Staiman VR, O'Toole KM, Rubin MA, Lowe FC. Giant malignant fibrous histiocytoma of the testis/spermatic cord: psychologic and possible etiologic complications of unethical Nazi medical experimentation. Urology 1996;48:939-43.
36. Hyouchi N, Yamada T, Takeuchi S, Machida T, Kanou H, Tanizawa A, Kamata S, Saitoh H. Malignant fibrous histiocytoma of spermatic cord: a case report. Acta Urol Jpn 1996; 42:469-71.

37. Schwartz SL, Swierzewski SJ III, Sondak VK, Grossman HB. Liposarcoma of the spermatic cord: report of 6 cases and review of the literature. J Urol 1995;153:1154-7.

38. Hendricks WH, Chu YC, Goldblum JR, Weiss SW. Dedifferentiated liposarcoma. A clinicopathological analysis of 155 cases with a proposal for an expanded definition of dedifferentiation. Am J Surg Pathol 1997;21:271-81.

39. Oliveira AM, Nascimento AG, Lloyd RV. Leptin and leptin receptor mRNA are widely expressed in tumors of adipocytic differentiation. Mod Pathol 2001;14:549-55.

40. Leuschner I, Newton WA Jr, Schmid D, Sachs N, Hamoud A, Asmar L, Harms D, Maurer HM. Spindle cell variants of embryonal rhabdomyosarcoma in the paratesticular region. A report of the Intergroup Rhabdomyosarcoma study. Am J Surg Pathol 1993;17:221-30.

41. Vallat-Decouvelaere A, Dry SM, Fletcher CDM. Atypical and malignant solitary fibrous tumors in extrathoracic locations: evidence of their comparability to intra-thoracic tumors. Am J Surg Pathol 1998;22:1501-11.

42. Khalidi HS, Singleton TP, Weiss SW. Inflammatory malignant fibrous histiocytoma: distinction from Hodgkin's disease and non-Hodgkin's lymphoma by a panel of leukocyte markers. Mod Pathol 1997;10:438-42.

43. Fagundes MA, Zietman AL, Althausen AF, Coen JJ, Shipley WU. The management of spermatic cord sarcoma. Cancer 1996;77:1873-6. 